\title{
Meningkatkan Kemampuan Berbicara Monolog Teks Recount dengan Metode Demonstrasi Media Picture Series
}

\author{
Purna Supriyati \\ SMA Negeri 1 Srandakan \\ Jln. Pandansimo KM 1 Srandakan Bantul Daerah Istimewa Yogyakarta Indonesia 55762 \\ Email: purnasmasra@gmail.com
}

\begin{abstract}
ABSTRAK
PTK ini dilatarbelakangi rendahnya kemampuan peserta didik berbicara monolog teks recount. Untuk mengatasi permasahan tersebut, digunakanlah metode demonstrasi media picture series. Subyek PTK ini adalah peserta didik kelas X SMA Negeri 1 Srandakan yang berjumlah 32 orang. Metode pengumpulan datanya adalah observasi dan tes, dan analisis datanya dengan metode komparatif kritis dan deskriptif. Hasil penelitiannya menunjukkan bahwa keaktifan belajar peserta didik mencapai 87,50\%. Pada siklus 1, ratarata nilai prestasi hasil belajarnya sebesar 75,16 , dan ketuntasan belajarnya mencapai $81,25 \%$. Pada siklus 2, rata-rata nilai prestasi hasil belajarnya meningkat jadi 80,08 , dan ketuntasan belajarnya mencapai 90,06\%. Angka ini melampaui persentase ketuntasan dengan kriteria baik, yaitu $80 \%$. Kesimpulannya, penggunaan media picture series berhasil meningkatkan kemampuan berbicara teks recount peserta didik kelas X SMA Negeri 1 Srandakan.
\end{abstract}

Kata Kunci: berbicara monolog, teks recount, metode demonstrasi, media picture series

\begin{abstract}
The classroom action research (CAC) aimed to solve the 32 SMA Negeri 1 Srandakan Yogyakarta Grade $X$ students' low competence of recount text monologue. The CAC applied the method of picture series demonstration. The data was collected with observation and testing methods and analyzed with critically comparative and descriptive methods. The research result showed that the students' activeness is $87.50 \%$. In the first cycle, the students' test score at average is 75.16 and the mastery of learning is $81.25 \%$. In the second cycle, the students' test score at average is 80.08 and the mastery of learning is $90.06 \%$ that is higher than $80 \%$, the fair score of the mastery of learning. It concluded that the application of the method of picture series demonstration successfully improved the SMA Negeri 1 Srandakan Grade X students' competence of recount text monologue.
\end{abstract}

Keywords: speaking monologue, recount text, demonstration method, picture series media

\section{PENDAHULUAN}

Sesuai dengan kurikulum SMA 2013 yang direvisi pada 2016, mata pelajaran Bahasa Inggris SMA menekankan empat keterampilan berbahasa, yaitu menyimak, berbicara, membaca dan menulis. Dari keempat keterampilan berbahasa ini, berbicara adalah salah satu keterampilan yang harus dikuasai oleh peserta didik untuk menyampaikan gagasan dalam bentuk tulisan.

Pelajaran Bahasa Inggris SMA berfokus pada penggunaan genre (jenis teks). Beberapa jenis teks yang dipelajari dan dikuasai oleh siswa SMA kelas X adalah recount, 
narrative, procedure, descriptive, dan news item. Tulisan ini mengkaji teks recount dalam aktivitas berbicara monolog berdasarkan hasil penelitian empiris. Aspek-aspek berbicara monolog meliputi kosakata (vocabulary), kelancaran (fluency), tata bahasa (grammar), koherensi (coherence), pengucapan (pronunciation), ketepatan (accuracy), pemahaman (understanding), dan kepercayaan diri (confidence).

Permasalahan dalam pembelajaran berbicara adalah bahwa sebagian besar peserta didik mengalami kesulitan untuk mengungkapkan apa yang ingin disampaikan secara lisan dalam Bahasa Inggris sesuai dengan kompetensi dasar yang diharapkan. Kesulitan ini terlihat pada hasil ulangan peserta didik dalam berbicara teks recount. Nilai rata-rata prestasi belajar kelas X SMA Negeri 1 Srandakan 2018/2019 adalah 66,64, dan ketuntasan belajarnya mencapai $71,87 \%$. Artinya, ada 23 peserta didik dari 32 peserta didik yang sudah tuntas belajar, sementara 9 peserta didik lainnya belum tuntas belajar. Kriteria ketuntasan minimal prestasi belajarnya adalah 67. Angka-angka ini menunjukkan bahwa secara klasikal peserta didik belum tuntas belajar, karena peserta didik yang memperoleh nilai $\geq 67$ hanya $71,87 \%$. Alhasil, pembelajaran ketrampilan berbicara teks recount belum berhasil mencapai kriteria ketuntasan minimal.

Penyebab ketidakberhasilan pencapaian kriteria ketuntasan minimal adalah penerapan metode pembelajaran yang tidak tepat. Metode pembelajaran yang diterapkan adalah ceramah. Maka, solusinya adalah perubahan metode pembelajaran dari ceramah ke metode demonstrasi media picture series. Metode pembelajaran demonstrasi media picture series diterapkan pada pokok bahasan berikutnya.

Tulisan ini menjawab dua pertanyaan, yakni (1) Bagaimana proses pembelajaran dengan metode demonstrasi media picture series pada pembelajaran berbicara monolog teks recount di SMA Negeri 1 Srandakan? (2) Apakah metode demonstrasi media picture series meningkatkan kemampuan peserta didik kelas X SMA Negeri 1 Srandakan dalam berbicara monolog teks recount?

\section{Berbicara}

Pengertian berbicara (speaking) menurut pendapat Tarigan (1986: 3) adalah kemampuan seseorang dalam mengucapakan bunyi-bunyi artikulasi atau kata-kata yang bertujuan untuk mengekspresikan, menyatakan serta menyampaikan pikiran, gagasan orang tersebut. Sementara itu, Brown dan Yule dalam Nunan (1989: 26) mengemukakan bahwa berbicara adalah penggunaan bahasa lisan yang terdiri dari ucapan yang pendek, tidak utuh atau terpisah-pisah dalam lingkup pengucapan. Pengucapan tersebut berhubungan sangat erat secara timbal balik antara pembicara dan pendengar. 
Aktivitas berbicara mempunyai tujuan, bentuk, dan fungsi. Richards dan Renandya (2002: 209-210) membagi aktivitas berbicara jadi empat: lisan, gambar, bantuan material, dan kesadaran budaya. Terdapat empat tujuan berbicara Tarigan (1995: 149), yakni menghibur, menginformasikan, menstimulasi berbicara, dan mengggerakkan dalam berbicara. Sementara itu, bentuk-bentuk berbicara berupa: berbicara di muka umum, berbicara dalam konferensi, prosedur parlementer, dan berdebat (Tarigan, 1981: 22-23). Menurut Richards (2003: 21), fungsi berbicara antara lain interaksi, transaksi, dan kinerja publik.

Untuk menjadi pembicara yang baik, seseorang harus menguasai masalah yang sedang dibicarakan dan harus berbicara dengan jelas dan tepat (Assjad dan Mukti, 1993: 17-20). Beberapa faktor yang perlu diperhatikan agar aktivitas berbicaranya efektif adalah kebahasaan (ucapan, diksi, tata bahasa, kosakata, sasaran pembicara) dan non-kebahasaan (ketenangan, volume suara, kelancaran, pemahaman). Keterampilan berbicara diuji dengan teknik-teknik monolog, interviu, dan free conversation.

Monolog ialah pidato panjang oleh seorang pembicara, khususnya orang yang mendominasi percakapan. Dalam pembelajaran berbicara, monolog berarti seorang peserta didik yang berpidato di kelas. Monolog merupakan salah satu teknik berbicara satu arah untuk menyampaikan pikiran dan perasaan kepada pendengar tanpa interaksi timbal balik pembicara-pendengar secara langsung.

\section{Metode demonstrasi}

Metode demonstrasi menurut Djamarah, Bahri dan Zain (2010: 90-91) adalah cara penyajian pelajaran dengan memperagakan atau mempertunjukkan suatu proses, situasi, atau benda tertentu yang sedang dipelajari, baik sebenarnya ataupun tiruan, yang sering disertai penjelasan lisan. Dengan metode demonstrasi, proses penerimaan peserta didik terhadap pelajaran lebih berkesan secara mendalam, sehinga membentuk pengertian dengan baik dan sempurna. Juga, peserta didik dapat mengamati dan memperhatikan apa yang diperlihatkan selama pelajaran berlangsung.

Metode demonstrasi mempunyai kelebihan dan kekurangan. Kelebihannya adalah (1) membuat pengajaran menjadi lebih jelas dan lebih konkret, sehingga menghindari verbalisme (pemahaman atas kata-kata atau kalimat), (2) peserta didik lebih mudah memahami apa yang dipelajari, (3) proses pengajaran lebih menarik, dan (4) peserta didik dirangsang untuk aktif mengamati, menghubungkan antara teori dan kenyataan, dan mencoba melakukannya sendiri. 
Kekurangannya ialah (1) tidak memerlukan keterampilan guru secara khusus, sehingga pelaksanaan demonstrasi tidak efektif. (2) Metode demonstrati membutuhkan fasilitas yang baik (peralatan dan tempat) dan biaya yang memadai, tetapi semua ini tidak selalu tersedia. (3) Demonstrasi memerlukan kesiapan dan perencanaan yang matang di samping memerlukan waktu yang cukup panjang dan mungkin terpaksa mengambil waktu atau jam pelajaran lain.

\section{Teks recount}

Teks recount merupakan salah satu jenis teks dalam pembelajaran Bahasa Inggris yang memiliki fungsi untuk menceritakan kembali kejadian atau pengalaman yang terjadi di masa lalu. Teks ini bertujuan untuk memberikan informasi dan atau menghibur pembaca yang membaca tulisan tersebut.

Ada tiga macam teks recount, yaitu personal recount, factual recount, dan imaginative recount. Personal recount berfungsi untuk menceritakan pengalaman pribadi penulis. Factual recount berfungsi untuk menyajikan laporan peristiwa yang benar-benar terjadi, seperti laporan penelitian. Imaginative recount berfungsi untuk menyajikan cerita imajinatif.

Teks recount mempunyai tiga struktur, yakni orientation, event, dan reorientation. Orientation berisi pengenalan, informasi yang diperlukan pembaca untuk memahami keseluruhan teks. Event berisi penyampaian atau kisah kejadian atau peristiwa. Reorientation berisi pengulangan pengenalan yang ada di tahap pertama dan juga berisi komentar atau kesan personal terhadap peristiwa atau kejadian yang telah terjadi. Tiga struktur teks recount bercirikan: (1) menggunakan kalimat past tense, (2) menggunakan action verb, (3) menggunakan adverb dan adverbial phrase untuk menggunakan waktu, tempat, waktu dan cara, dan (4) menggunakan conjunction dan time connection.

\section{Media picture series}

Media picture series atau gambar seri, menurut Arsyad (2011: 23), merupakan serangkaian gambar yang terdiri dari 2-6 gambar yang menceritakan suatu kesatuan cerita yang dapat dijadikan alur pemikiran. Setiap gambar dalam media gambar berseri mengandung makna dan alur dalam suatu cerita. Picture series mempunyai urutan kejadian yang memiliki satu kesatuan cerita.

Gambar berseri membantu peserta didik untuk melatih dan mempertajam imajinasi yang kemudian dituangkan dalam bentuk ucapan. Semakin tajam daya imajinasi siswa, semakin berkembang pula peserta didik dalam melihat membahasakan sebuah gambar. Picture series mempunyai banyak manfaat dalam proses belajar mengajar (Sudjana dan 
Rivai dalam Arsyad, 2011: 24). (1) Pembelajaran dengan picture series lebih menarik perhatian peserta didik sehingga menumbuhkan motivasi belajar. (2) Pembelajaran menjadi lebih jelas sehingga lebih dipahami oleh siswa dan memungkinkan peserta didik untuk menguasai dan mencapai tujuan pembelajaran. (3) Metode mengajar lebih bervariasi, tidak semata-mata komunikasi verbal melalui penuturan kata-kata oleh guru, sehingga peserta didik tidak bosan dan guru tidak kehabisan tenaga, apalagi kalau guru mengajar pada setiap jam pelajaran. (4) Peserta didik dapat lebih banyak melakukan kegiatan belajar, sebab tidak hanya mendengarkan uraian guru, tetapi juga aktivitas lain, seperti mengamati, melakukan, mendemonstrasikan, dan memerankan.

Langkah-langkah penggunaan media gambar berseri dapat disusun sebagai berikut. (1) Guru mempersiapkan gambar-gambar sesuai dengan tujuan pembelajaran. (2) Guru menempelkan gambar di papan atau ditayangkan di layar. (3) Guru memberi petunjuk dan memberi kesempatan pada peserta didik untuk memperhatikan atau menganalisis gambar. (4) Peserta didik dibagi jadi kelompok-kelompok yang beranggotakan 2-3 orang untuk mendiskusi gambar tersebut dan mencatat hasil diskusinya pada kertas. (5) Tiap kelompok diberi kesempatan untuk membacakan hasil diskusinya. (6) Guru menjelaskan materi sesuai dengan tujuan. (7) Peserta didik membuat kerangka karangan.

\section{METODE PENELITIAN}

Penelitian ini menggunakan metodologi penelitian tindakan kelas (PTK), yang dilakukan secara kolaboratif. Guru-guru Bahasa Inggris SMA Negeri 1 Srandakan Bantul Daerah Istimewa Yogyakarta bekerja sama dalam pengambilan data saja. Penelitiannya dilakukan pada bulan Januari-Maret 2019. Tempat penelitiannya di SMA Negeri 1 Srandakan. Subyek penelitiannya adalah peserta didik kelas X yang berjumlah 32 orang. PTK memiliki empat tahap penelitian (Arikunto dkk., 2007: 18), yaitu preencanaan (planning), tindakan (action), pengamatan (observation), dan refleksi (reflection).

Pengumpulan datanya memakai metode-metode observasi dan tes. Data yang dikumpulkan berupa pengetahuan (knowledge), sikap (attitude) dan tingkah laku (action). Tiga jenis data ini diperinci jadi kosakata (vocabulary), kelancaran (fluency), tata bahasa (grammar), koherensi (coherence), pengucapan (pronunciation), ketepatan (accuracy), pemahaman (understanding), dan kepercayaan diri (confidence).

Selanjutnya, data hasil observasi dan tes tersebut dianalisis dengan menggunakan teknik analisis komparatif dan kritis. Teknik komparatif adalah membandingkan $\underline{\text { antarsiklus (Sutama, 2010: 52), yaitu siklus I dan siklus II. Analisis data pada tahap }}$ 
berikutnya adalah analisis deskriptif, yaitu mendeskripsikan kinerja peserta didik dan guru dalam proses belajar mengajar berdasarkan kriteria normatif yang diturunkan dari kajian teoretis. Hasil analisis tersebut dijadikan dasar dalam menyusun perencanaan tindakan untuk tahap berikutnya sesuai dengan siklus yang ada (Sutama dan Main 2010: 52).

\section{HASIL PENELITIAN DAN PEMBAHASAN}

\section{Hasil observasi}

Hasil observasi selama pembelajaran menunjukkan bahwa penerapan metode demonstrasi picture series meningkatkan aktivitas peserta didik di kelas. Dibandingkan dengan kondisi awal, keterampilan berbicara monolog siswa pada siklus 1 dan 2 mengalami peningkatan secara signifikan. Peningkatan tersebut tampak dalam Grafik 1.

Keaktifan siswa pada siklus 2 pertemuan 1 adalah 84,37\%, dan pertemuan 2 meningkat jadi 87,50\%. Rata-rata keaktifan belajar peserta didik pada siklus 2 adalah $85,93 \%$. Jika dibandingkan dengan siklus 1 yang keaktifan belajarnya $76.86 \%$, terdapat peningkatan sebesar 9,07\%. Jika dibandingkan dengan kondisi awal yang keaktifan belajarnya $70 \%$, terjadi peningkatan sebesar $15,93 \%$. Dengan demikian, setelah penerapan metode demonstasi media picture series, keaktifan belajar peserta didik meningkat secara signifikan.

Grafik 1. Hasil Observasi Pembelajaran

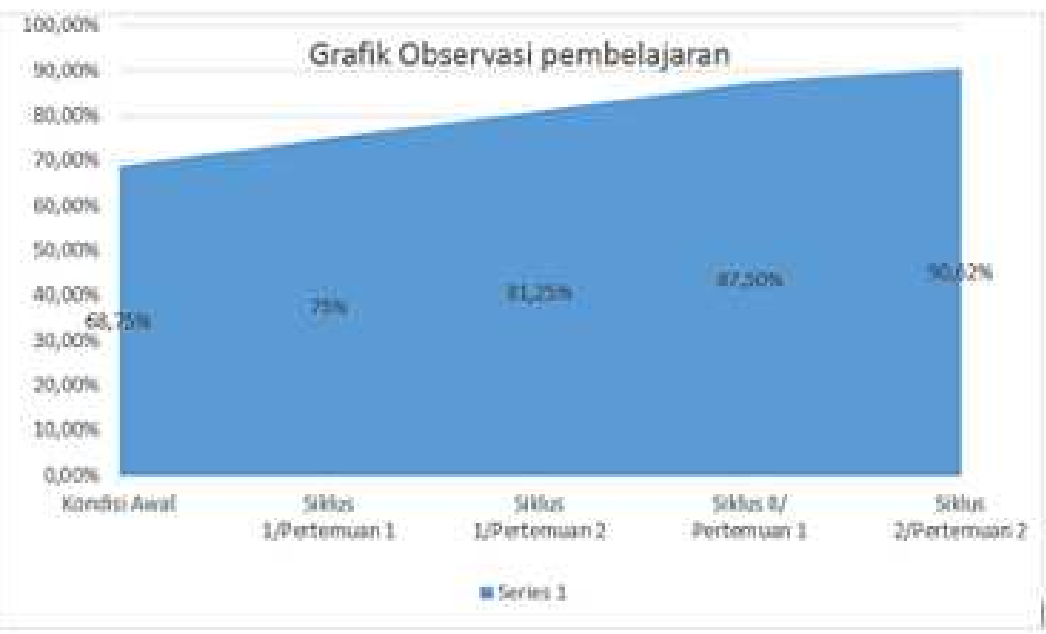

Hasil observasi saat pelaksanaan pembelajaran pada siklus 1 dan siklus 2 juga menunjukkan bahwa para peserta didik berpartisipasi secara aktif dalam proses pembelajaran. Ini bisa dilihat dari data kehadiran peserta didik dalam setiap kegiatan pembelajaran yang selalu 100\%. Pada awal pembelajaran di siklus 1 dan 2, peserta didik 
sibuk menata dan menyiapkan picture series, yang berupa foto-foto mereka sendiri di waktu lampau. Mereka mengamati foto-fotonya dan merancang presentasinya.

Kemudian, mereka melihat foto-foto temannya sambil menanyakan hal-hal terkait dengan foto-foto tersebut, seperti tempat, waktu, dan bersama siapa. Mereka saling komentar mengenai foto-foto tersebut. Mereka tampak bangga dengan foto-fotonya sendiri, dan menghargai dan antusias dengan foto-foto temannya.

Selanjutnya, mereka melakukan pemodelan dan presentasi tampil berbicara monolog di depan kelas. Peserta didik dipanggil oleh guru untuk maju satu persatu. Sebagian peserta didik tampil percaya diri dalam mendemonstrasikan media picture seriesnya. Sebagian lainnya masih kurang percaya diri. Pada waktu tampil berbicara, sebagian peserta didik lancar, sementara sebagian lainnya masih kurang lancar.

Peserta didik tertarik dan termotivasi pada saat proses pembelajaran keterampilan berbicara teks recount. Mereka memperhatikan teman-temannya yang tampil berbicara mendemonstrasikan media picture series, walaupun sesekali memperhatikan picture series yang dipersiapkan sendiri. Hal ini dapat dimaklumi karena mereka akan tampil berbicara di depan kelas dengan mendemonstrasikan picture series. Mereka dengan bangga mendemonstrasikan media picture series sebagai hasil karyanya dan menceritakan kegiatan tentang picture series tersebut secara runtut dan percaya diri. Terjadi interaksi positif antara peserta didik sebagai pembicara dan peserta didik lainnya sebagai pendengar. Mereka saling belajar sehingga semua peserta didik menyempurnakan kemampuan berbicara mereka.

Peserta didik bersama guru selalu melakukan refleksi pada setiap tahapan presentasi ketrampilan berbicara yang mereka lakukan. Guru memberikan ulasan atas tampilan mereka terkait dengan aktivitas peserta didik. Evaluasi dan umpan balik tersebut sangat efektif untuk meningkatkan kualitas aktivitas peserta didik.

\section{Hasil tes}

Grafik 2 menunjukkan bahwa nilai rata-rata prestasi belajar peserta didik pada siklus 1 adalah 75,16 dan ketuntasan belajar mencapai 81,25\%. Artinya, terdapat 26 peserta didik yang sudah tuntas belajar dari 32 peserta didik yang hadir dalam proses belajar dan tes. Pada siklus 2, rata-rata nilai hasil belajar 80,08 dan ketuntasan belajarnya mencapai 90,06\%. Artinya, terdapat 29 peserta didik yang telah tuntas belajar dari 32 peserta didik yang hadir dalam proses belajar dan tes. Dengan perkataan lain, ketuntasan belajar klasikal mengalami peningkatan yang signifikan dan lebih baik dari pada siklus 1, yang rata-rata nilai siswa 75,16 . 
Grafik 2. Hasil Tes Pra-siklus, Siklus 1 dan Siklus 2

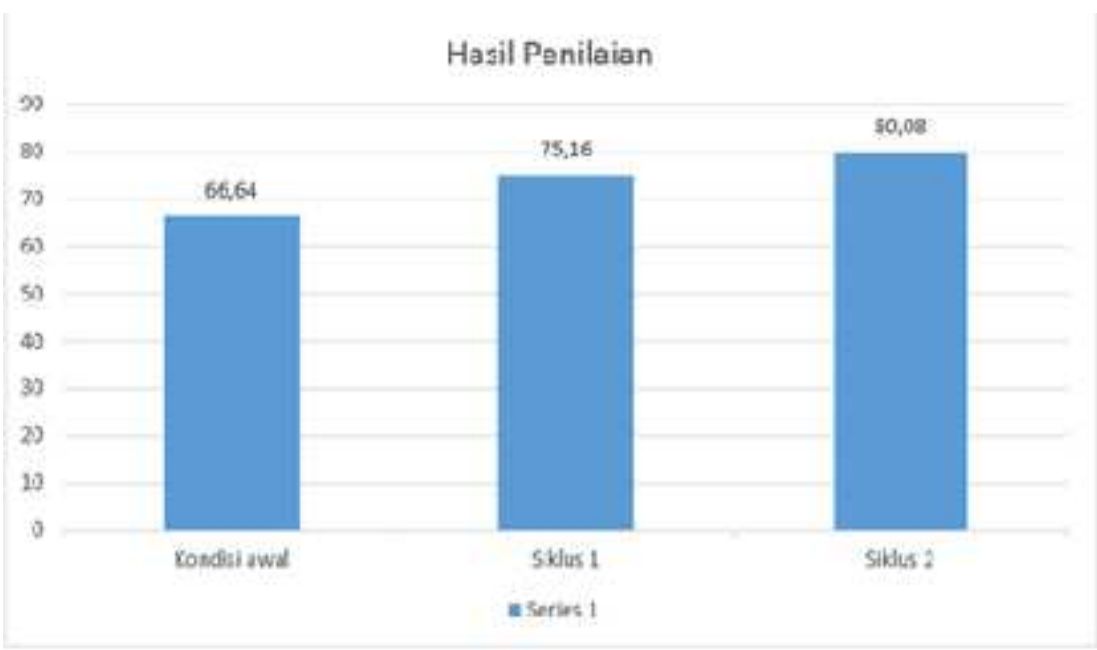

Jika hasil belajar siklus 1 dibandingkan dengan pada kondisi awal yang rata-rata prestasi belajarnya 66,64 dan yang ketuntasan belajarnya 25 orang (78,12\%), hasil belajarnya meningkat sebesar 3,13\%. Jika hasil belajar pada siklus 2 dibandingakan dengan pada siklus awal, ketuntasan belajarnya meningkat sebesar 11,94\%. Pemanfaatan media picture series efektif untuk meningkatkan kemampuan berbicara peserta didik pada teks recount.

\section{KESIMPULAN}

Kesimpulannya adalah pertama proses pembelajaran dengan metode demonstrasi media picture series pada pembelajaran berbicara monolog teks recount di SMA Negeri 1 Srandakan berlangsung dengan baik. Para peserta didik bersemangat dan antusias untuk menyiapkan dan melakukan monolognya. Keaktifan siswa pada siklus 2 pertemuan 1 adalah 84,37\%, dan pertemuan 2 meningkat jadi 87,50\%. Rata-rata keaktifan belajar peserta didik pada siklus 2 adalah 85,93\%. Keaktifan belajar mereka pada siklus 1 sebesar 76.86\% dan pada siklus 2 meningkat sebesar 9,07\%. Pada kondisi awal, keaktifan belajarnya $70 \%$ dan pada siklus 2 meningkatan sebesar 15,93\%.

Kedua metode demonstrasi media picture series berhasil meningkatkan kemampuan peserta didik kelas X SMA Negeri 1 Srandakan dalam berbicara monolog teks recount. Rata-rata prestasi bejalar peserta didik meningkat dari 66,64 pada kondisi awal ke 75,16 pada siklus 1 dan 80.08 pada siklus 2 . Ketuntasan belajarnya pun meningkat dari $78,12 \%$ pada kondisi awal ke 81,25\% pada siklus 2 dan 90,06\% pada siklus 2 . 


\section{DAFTAR PUSTAKA}

Arsyad, Azhar. 2011. Media Pembelajaran. Jakarta: PT Raja Grafindo Persada.

Syah, Muhibbin. 2000. Psikologi Pendidikan dengan Pendekatan Baru. Bandung: Remaja Rosda Karya

Sudjana, Nana. 1984. Dasar-dasar Belajar Mengajar. Bandung: Sinar Baru Algesindo

Nunan, David. 1989. Designing Task for the Communicative Classroom. Cambridge: Cambridge University Press

Richards, J. C. dan Renandya, W. A. 2002. Methodology in Language Teaching: An Anthology of Current Practices. New York: Cambridge University Press

Suharsimi, Arikunto. 2007. Penelitian Tindakan Kelas. Jakarta: PT. Bumi Aksara

Sutama, Main Sufanti. 2010. PTK dan Karya Ilmiah. Surakarta: Badan Penerbit FKIP Universitas Muhammadiyah Surakarta

Djamarah, Syaiful Bahri dan Aswan Zain. 2010. Strategi Belajar Mengajar. Jakarta: Rineka Cipta

Tarigan, Henry Guntur. 1981. Berbicara Sebagai Suatu Keterampilan Berbahasa. Bandung: Angkasa. 